\title{
The influence of glow-discharge nitriding on the properties of thermally sprayed steel coatings
}

\author{
Keywords: \\ thermal spraying; \\ arc spraying; \\ glow-discharge nitriding; \\ coating $\mathrm{X} 46 \mathrm{Cr} 13$; \\ coating X2CrNi18-9; \\ Vickers hardness; \\ wear resistance; \\ Amsler method
}

\begin{abstract}
Hybrid technologies are one of the directions of materials engineering development. They contribute to the subject of research on improving the performance of thermally sprayed steel coatings by thermo-chemical treatment.

The paper presents the test results of arc spraying stainless steel coatings and then glow-discharge nitrided. The glow-discharge nitriding was performed with the following parameters: at $450{ }^{\circ} \mathrm{C}$ for 6 hours and at $530^{\circ} \mathrm{C}$ for 4 hours. The results of the following tests are described and presented: metallographic (SEM), qualitative and quantitative analysis point EDS, measurement of hardness HV, hardness distribution, measurement of roughness parameters $(\mathrm{Ra}, \mathrm{Rz})$, wear resistance by the Amsler method.

The results showed that the glow-discharge nitriding increases the hardness and the frictional wear resistance of thermal sprayed stainless steel $\mathrm{X} 46 \mathrm{Cr} 13$ and $\mathrm{X} 2 \mathrm{CrNi18}-9$ coatings. The hybrid technology, combining thermal spraying of martensitic stainless steel $\mathrm{X} 46 \mathrm{Cr} 13$ and glow-discharge nitriding at $530{ }^{\circ} \mathrm{C}$ for 4 hours, provides formation of a coating with the highest hardness and wear resistance of all the tested coatings. This coating can be applied to the regeneration of machine parts, which are required to have particularly high useful properties.
\end{abstract}

\section{Introduction}

Thermal spraying technology is used to apply coatings on new machine parts in order to improve the usable properties of their surfaces or to regenerate worn parts $[1 \div 8]$. As a result of regeneration, the parts are repaired and their dimensions are restored, their durability is significantly increased, and thus the life of the device, part of which is covered by the coating [9], becomes longer. A thermally sprayed stainless steel, especially austenitic steel used for regeneration often have too low hardness and abrasion resistance. In order to increase the properties of thermal sprayed coatings, one of the surface engineering technologies can be used. Such technology, improving both mechanical properties, e.g. hardness, resistance to wear, as well as anti-corrosion properties of the surface layers by modification of its chemical composition and microstructure is called glow-discharge nitriding. The glow-discharge nitriding technology is more and more widely used in industry as an effective and economical method of increasing the usable properties of machine parts and tools. The advantage of this method is the ability to precisely regulate the structure of the nitrided layer, conduct the process at a temperature of as little as $400{ }^{\circ} \mathrm{C}$, and the ability to regulate the phase composition of the produced layers by changing the chemical composition of the reactive atmosphere, which allows the production of composite layers in one technological process. The economic competitiveness in relation to classic gas technologies results from the low consumption of electricity and gas atmosphere components, and in particular from the reduction of costs of labor-intensive finishing operations due to

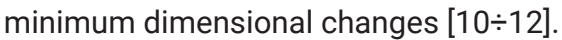

There are very few papers in national and world literature on the use of hybrid technology that combines two technologies of surface engineering: thermal spraying and glow-discharge nitriding. L. Berkowski studied selected regenerative

dr hab. inż. Tomasz Babul, prof. IMP; mgr inż. Anna Olbrycht; inż. Szymon Pawlik; inż. Janusz Trojanowski

- Institute of Precision Mechanics, Warsaw, Poland;

Corresponding author: anna.olbrycht@imp.edu.pl 
coatings applied by various methods nitrided with gas as well as glow-discharge [13]. He stated, that after glow-discharge nitriding at $520{ }^{\circ} \mathrm{C}$ for 8 hours, the coating of $4 \mathrm{H} 13$ steel sprayed with an arc method increases the hardness by about $600 \mathrm{HV} 0.1$, while the coating resistance to friction wear does not change. Paper [14] presents the results of tests of coatings sprayed thermally with $40 \mathrm{H} 13$ and $\mathrm{H} 18 \mathrm{~N} 10 \mathrm{~T}$ wires, which are then subjected to glow-discharge nitriding in various process parameters. A significant increase in hardness and abrasion resistance of coatings after glow-discharge nitriding was found. In the paper [15], plasma-sprayed austenitic 316 L corrosion-resistant steel was tested after low-temperature nitriding. A layer made of nitride phase "S" (S-phase), also known as expanded austenite, which increases the hardness of the surface while maintaining corrosion resistance, was found.

The paper investigates the effect of the glow-discharge nitriding process, with different process parameters, on the microstructure and properties of the thermally sprayed stainless steel coatings.

\section{Research methodology}

Coatings were sprayed using $\varnothing 2.5 \mathrm{~mm}$ steel wires: austenitic X2CrNi18-9 (1.4307/304L)(C <0.03\%, $\mathrm{Si}<1.0 \%$, Mn $<2.0 \%$,

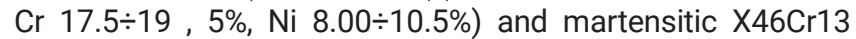
(1.4034/4H13) (C 0.45\%, Mn 0.5\%, Si 0.6\%, Cr 13.5\%, Mo 0.5\%, $\mathrm{V} 0.2 \%)$. An LD-U2 type arc spray gun manufactured by OSU-Maschinenbau was used to spray the coatings. The coatings were sprayed on two types of samples: for steel samples 42CrMo4 (1.7225/40HM) ø25 mm (for metallographic and hardness tests) and for samples made of X2CrNi18-9 steel with dimensions of $25 \times 10 \times 4 \mathrm{~mm}$ (for tribological tests). Prior to spraying, the samples were blasted using an electrocorundum with a granularity of 14 to obtain the surface cleanliness of $\mathrm{Sa} 3$ and the roughness of $\mathrm{R}_{\mathrm{y} 5}-45 \mu \mathrm{m}$. The thermally sprayed coatings were then subjected to glow-discharge nitriding under $\mathrm{N}_{2}: \mathrm{H}_{2}$ athmosphere at a ratio of $30 \%: 70 \%$ at the cathode potential with the following parameters: at $450{ }^{\circ} \mathrm{C}$ for 6 hours and at $530^{\circ} \mathrm{C}$ for 4 hours. Before nitriding, thermally coated surfaces were grinded.

The observation of the structure of thermal sprayed coatings as well as the qualitative and quantitative analysis was performed using a HITACHI S-3500N scanning microscope equipped with an EDS X-ray spectrometer. The measurement of hardness on the surface of the coatings was made using the STRUERS DURA SCAN 70 hardness testing machine. Wear resistance due to friction was determined on the friction-wear machine A-135 of the type Amsler in accordance with the $\mathrm{PN}-82 / \mathrm{H}-04332$ standard [16] in system of a plate (sample) with a thermally sprayed coating with dimensions of $25 \times 10 \times 4 \mathrm{~mm}$ and a roll (counter-sample) made of $40 \mathrm{H}$ tempered steel, hardness of $\sim 30 \mathrm{HRC}$. The rotational speed of the roll was $200 \mathrm{rpm}$. The test was performed under sliding friction conditions using Lux 10 oil and 20 daN load. The width and depth of traces of wear were measured with an accuracy of $0.01 \mathrm{~mm}$ using an optical microscope. The roughness parameters $\mathrm{Ra}$ and $\mathrm{Rz}$ of thermally sprayed grinded coatings before and after nitriding were determined by means of the TIME TR100 instrument with the measuring range Ra $0.05 \div 15.0 \mu \mathrm{m}$ and $\mathrm{Rz} 0.10 \div 50.0 \mu \mathrm{m}$.

\section{Test results}

\section{Metallographic tests}

Figure 1 shows photos of microstructures of $\mathrm{X} 46 \mathrm{Cr} 13$ and $\mathrm{X} 2 \mathrm{CrNi18}-9$ steel arc sprayed coatings: $\mathrm{a}, \mathrm{b}$ ) without nitriding; c, d) nitrided at $450{ }^{\circ} \mathrm{C}$ for 6 hours; e, f) nitrided at $530{ }^{\circ} \mathrm{C}$ for 4 hours.

The pictures show the structure typical for thermally sprayed coatings. The coatings have a compact structure and are characterized by a good connection to the substrate.

In the $\mathrm{X} 46 \mathrm{Cr} 13$ steel coating, after nitriding at $530{ }^{\circ} \mathrm{C}$ for 4 hours, a somewhat darker surface layer with a thickness of approx. $40 \mu \mathrm{m}$ is observed on the surface (Fig. 1e). This may indicate the presence of a nitrogen-saturated diffusion zone in the coating. The existence of this zone is confirmed by the results of qualitative and quantitative analysis performed using a scanning electron microscope equipped with EDS. The presence of nitrogen was found at a depth of approx. $50 \mu \mathrm{m}(1.74 \% \mathrm{wt}$.) and at a depth of $5 \mu \mathrm{m}-6.78 \% \mathrm{wt}$. nitrogen (Fig. 2). An equally deep diffusion of nitrogen was found in the case of nitriding $\mathrm{X} 2 \mathrm{CrNi18}-9$ steel coatings at $530{ }^{\circ} \mathrm{C}$ for 4 hours, however, the analysis carried out in three places indicates that it is uneven.

On the other hand, low-temperature nitriding at $450{ }^{\circ} \mathrm{C}$ for 6 hours of thermally sprayed coating made of X $46 \mathrm{Cr} 13$ steel causes nitrogen penetration to a depth of approx. $16 \mu \mathrm{m}$ (2.92\% wt.). The highest nitrogen content was found at a depth of $2.5 \mu \mathrm{m}$ (5.03\% wt.). The depth of diffusion of nitrogen into the thermally sprayed of $\mathrm{X} 2 \mathrm{CrNi18}-9$ steel after nitriding at $450{ }^{\circ} \mathrm{C}$ for 6 hours is lower than for $\mathrm{X} 46 \mathrm{Cr} 13$ steel and amounts to approx. $5 \mu \mathrm{m}$ (3.31\% wt.). A very thin layer was observed on the surface of the coating, in which the nitrogen content was $5.93 \%$ wt. (Fig. 3). It is known from the literature that this is so-called $\mathrm{S}$ phase, created on the surface of austenitic steel during low-temperature nitriding, which is a supersaturated solution of nitrogen in the austenite network $[12,15]$.

\section{Hardness measurements}

The analysis of results of HV0.1 hardness measurements made on the surface of thermally sprayed steel coatings $\mathrm{X} 46 \mathrm{Cr} 13$ before and after nitriding indicates that glow-discharge nitriding greatly increases the hardness of the tested coatings (Fig. 4). The highest hardness 1165 HV0.1 was obtained after nitriding at $450{ }^{\circ} \mathrm{C}$ for 6 hours, slightly lower 1108 HV0.1 after nitriding at $530^{\circ} \mathrm{C}$ for 4 hours.

Nitriding of thermally sprayed coatings from X2CrNi18-9 steel at $530{ }^{\circ} \mathrm{C}$ for 4 hours causes more than twice the increase in hardness on its surface to $1114 \mathrm{HV} 0.1$, while the hardness of HV0.1 on the surface of the coating after nitriding at $450{ }^{\circ} \mathrm{C}$ for 6 hours increased only at $11 \%$. To explain this phenomenon, an additional measurement of hardness was performed at a lower load - 10 G, it amounted to 1048 HV0.01. This testifies to the existence of a hard, but very thin layer on the surface of the coating, so-called phase $S$ formed on the surface of austenitic steel during low-temperature nitriding. The existence of this layer is confirmed by the photos taken on the scanning microscope and analysis of the chemical composition, showing the content of nitrogen in this layer within about $6 \%$ wt.

Hardness distributions made on metallographic specimens show that only glow-discharge nitriding at $530^{\circ} \mathrm{C}$ for 4 hours of heat-treated coating with $\mathrm{X} 46 \mathrm{Cr} 13$ causes an increase in hardness not only on its surface, but also at a depth of approx. $50 \mu \mathrm{m}$ (Fig. 5). These results coincide with the results of qualitative and quantitative EDS analysis. It was found that in this sample nitrogen penetrates to a depth of approx. $50 \mu \mathrm{m}$.

\section{Tribological tests}

The tests carried out with the Amsler A-135 wear-resistant machine showed an increase in wear resistance due to the friction of $\mathrm{X} 46 \mathrm{Cr} 13$ and $\mathrm{X} 2 \mathrm{CrNi18}-9$ thermally sprayed coatings after glow-discharge nitriding. Figures 6 and 7 show 
the average wear value $z$ (wear depth) depending on the friction time of the thermally sprayed steel coatings $\mathrm{X} 46 \mathrm{Cr} 13$ and $\mathrm{X} 2 \mathrm{CrNi} 18-9$ without nitriding and with nitriding.

Glow-discharge nitriding at $450^{\circ} \mathrm{C}$ for 6 hours of thermally sprayed $\mathrm{X} 46 \mathrm{Cr} 13$ steel coatings resulted in a twofold increase in wear resistance. An even better result was obtained after nitriding at $530{ }^{\circ} \mathrm{C}$ for 4 hours - a fourfold increase in wear resistance.

The thermal spray coating made of $\mathrm{X} 2 \mathrm{CrNi18}-9$ steel before nitriding has a higher wear resistance than the $\mathrm{X} 46 \mathrm{Cr} 13$ steel coating before nitriding (Fig. 7). After glow-discharge nitriding, the wear resistance of the friction increases, reaching a similar value as for the $\mathrm{X} 46 \mathrm{Cr} 13$ steel coating after nitriding. The best wear resistance of the $\mathrm{X} 2 \mathrm{CrNi18}-9$ steel coating was found, similar to the $\mathrm{X} 46 \mathrm{Cr} 13$ steel sprayed coating, after nitriding at $530{ }^{\circ} \mathrm{C}$ for 4 hours.

The measurement of roughness parameters $\mathrm{Ra}$ and $\mathrm{Rz}$ indicates a slight increase in the roughness of the thermally sprayed coatings from steel $\mathrm{X} 46 \mathrm{Cr} 13$ and $\mathrm{X} 2 \mathrm{CrNi18}-9$ after glow-discharge nitriding (Tab. I).

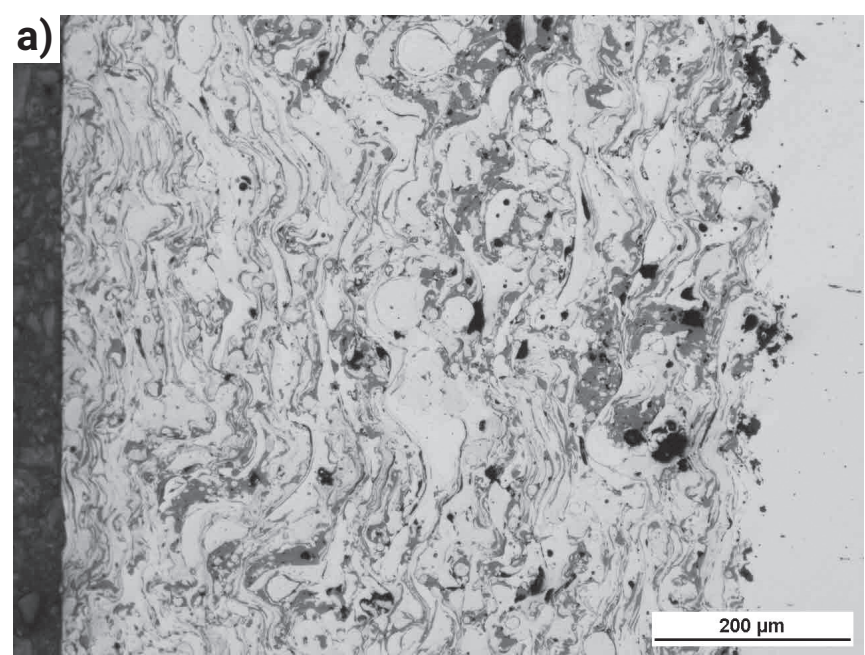

$\mathrm{X} 46 \mathrm{Cr} 13$, without nitriding

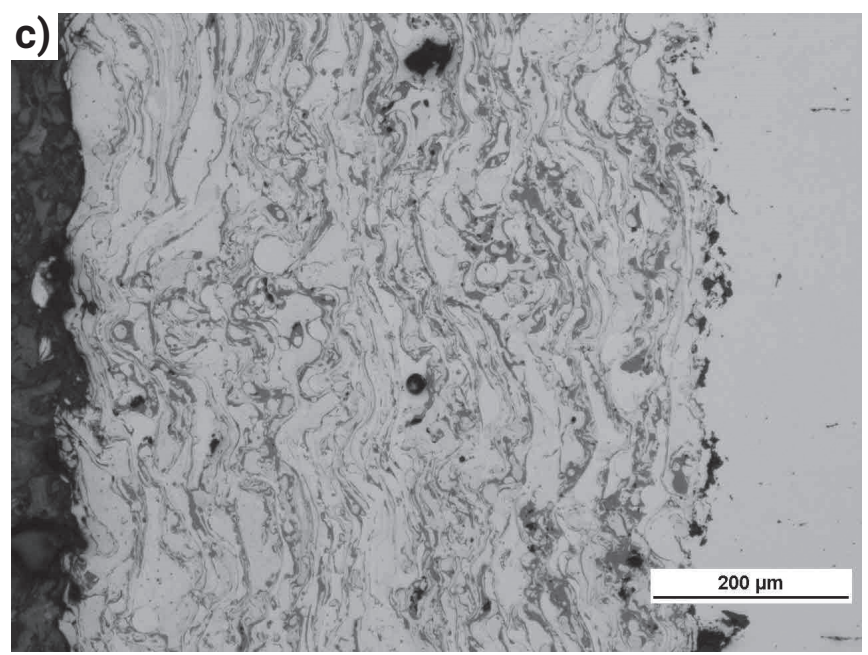

$\mathrm{X} 46 \mathrm{Cr} 13$, nitrided at $450{ }^{\circ} \mathrm{C}, 6 \mathrm{~h}$

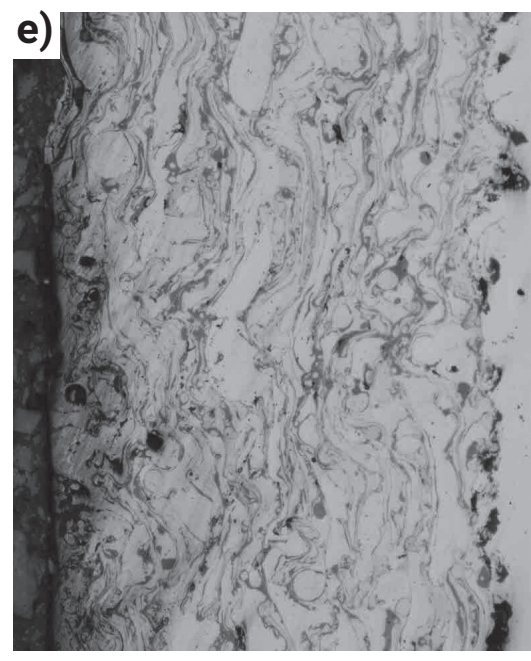

$\mathrm{X} 46 \mathrm{Cr} 13$, nitrided at $530^{\circ} \mathrm{C}, 4 \mathrm{~h}$

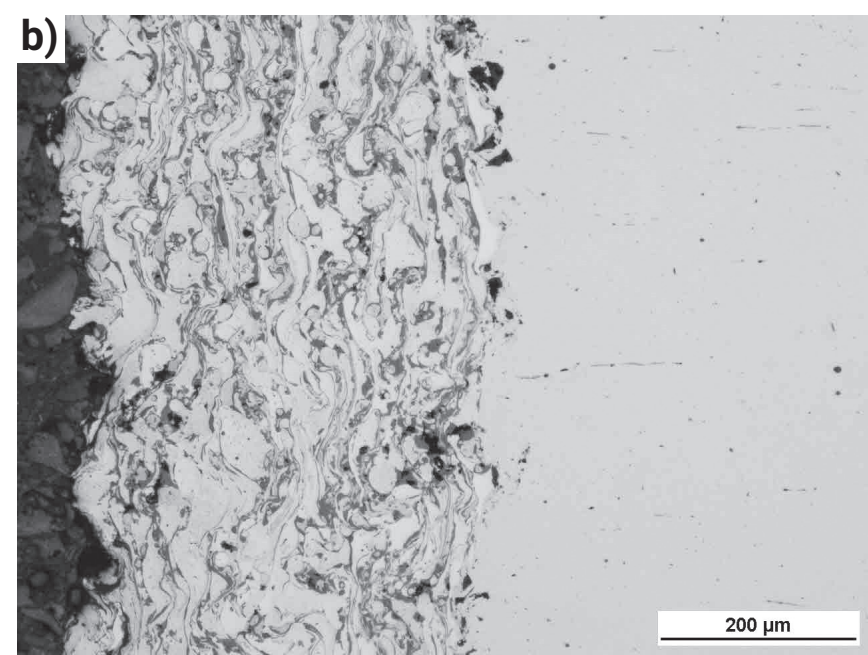

X2CrNi18-9, without nitriding

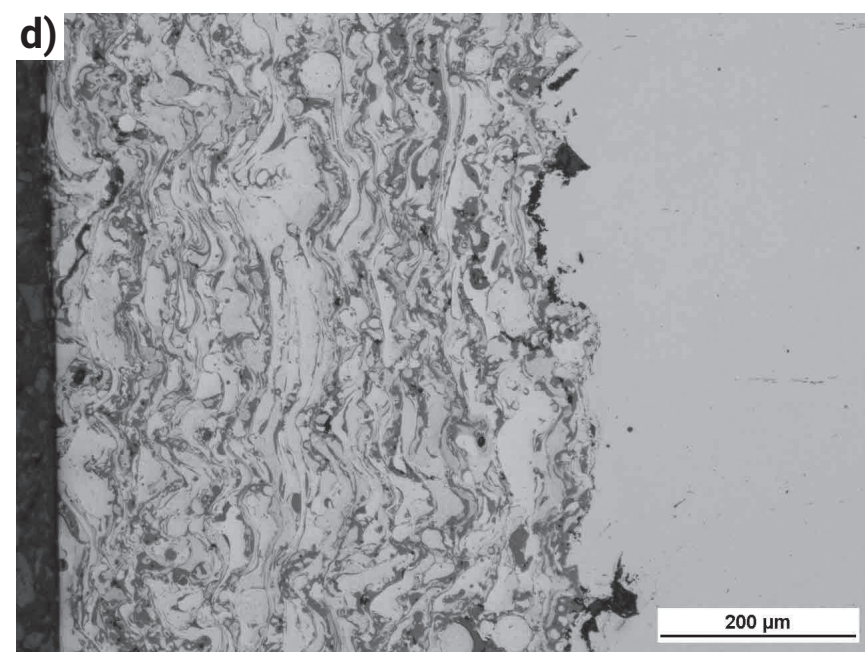

$\mathrm{X} 2 \mathrm{CrNi} 18-9$, nitrided at $450^{\circ} \mathrm{C}, 6 \mathrm{~h}$

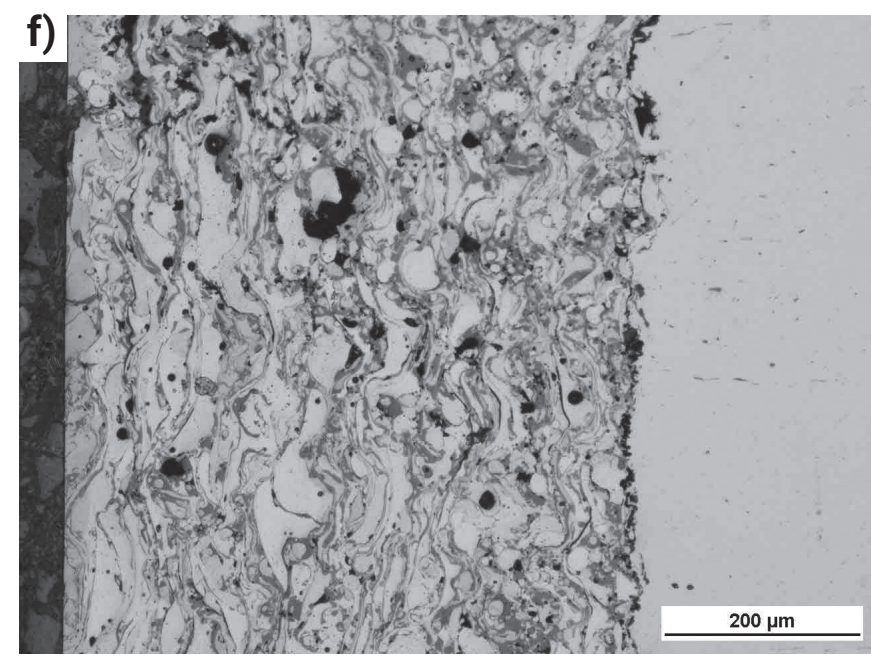

$\mathrm{X} 2 \mathrm{CrNi18}-9$, nitrided at $530^{\circ} \mathrm{C}, \mathbf{4} \mathrm{h}$

Fig. 1. Microstructure of non-etched thermally sprayed coatings of $\mathrm{X} 46 \mathrm{Cr} 13$ and $\mathrm{X} 2 \mathrm{CrNi1}-9$ steel on $42 \mathrm{CrMo} 4$ steel: a), b) without nitriding; c), d) nitrided at $450^{\circ} \mathrm{C}, 6 \mathrm{~h}$; e), f) nitrided at $530^{\circ} \mathrm{C}, 4 \mathrm{~h}$ 


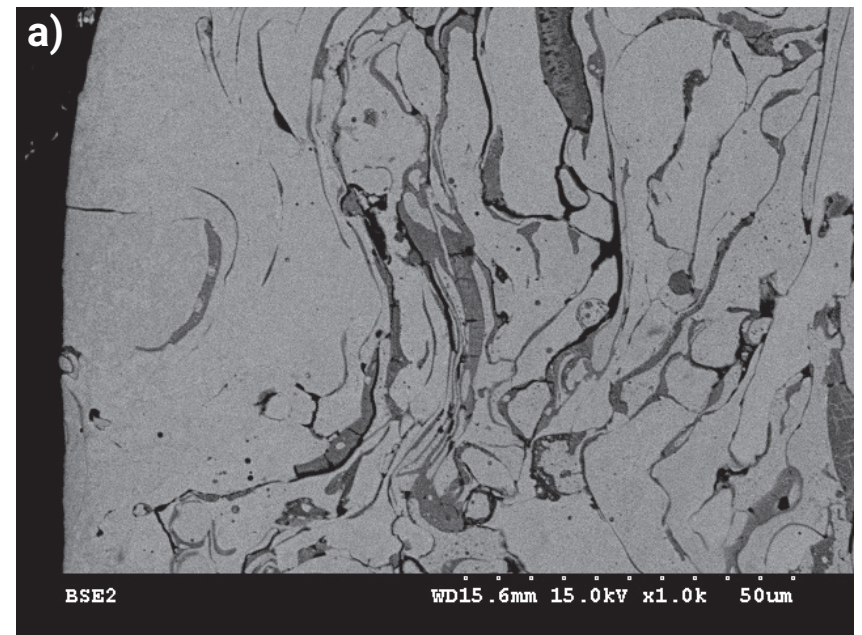

c)

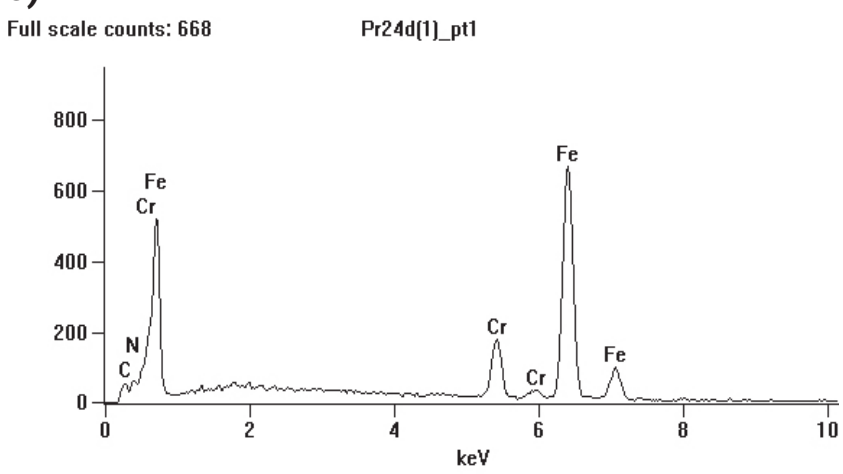

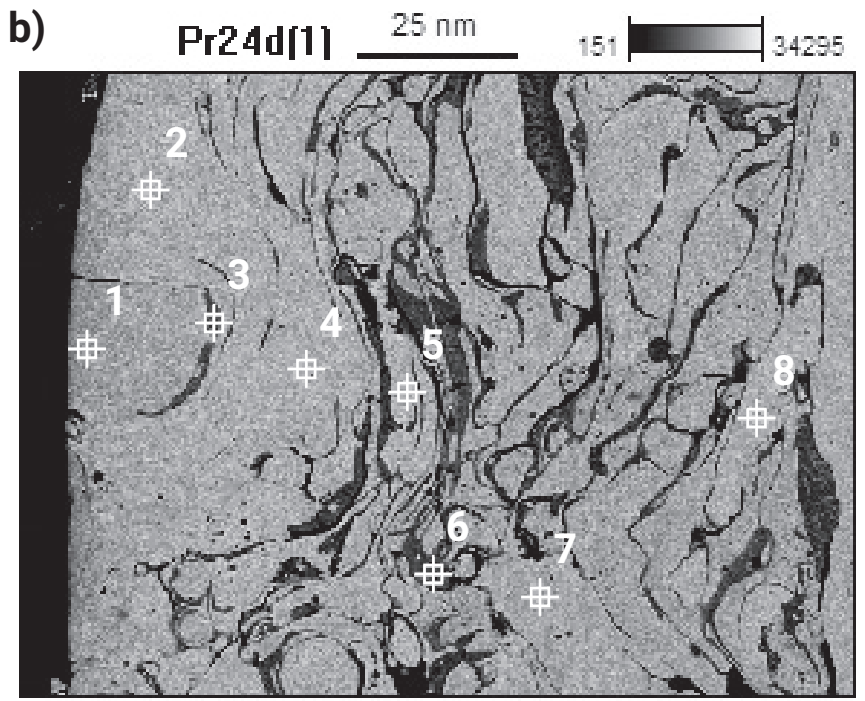

d)

\begin{tabular}{|c|c|c|c|c|c|c|}
\hline & C & N & O & Si & Cr & Fe \\
\hline Pr24d(1)_pt1 & 6,76 & 5,61 & & & 10,03 & 77,60 \\
\hline Pr24d(1)_pt2 & 10,22 & 2,68 & & & 11,19 & 75,92 \\
\hline Pr24d(1)_pt3 & 8,69 & & 13,32 & & 12,58 & 65,41 \\
\hline Pr24d(1)_pt4 & 6,94 & 2,50 & & & 11,88 & 78,68 \\
\hline Pr24d(1)_pt5 & 9,13 & 1,74 & & & 9,24 & 79,90 \\
\hline Pr24d(1)_pt6 & 8,11 & & 14,43 & & 22,99 & 54,47 \\
\hline Pr24d(1)_pt7 & 10,20 & & & & 11,86 & 77,93 \\
\hline Pr24d(1)_pt8 & 9,94 & & & 0,27 & 10,89 & 78,91 \\
\hline
\end{tabular}

Fig. 2. Coating sprayed of $X 46 \mathrm{Cr} 13$ steel after nitriding at $530{ }^{\circ} \mathrm{C}, 4 \mathrm{~h}$ : a) SEM images of the test sample; b) SEM images of the test sample with marking of the analyzed points; $c$ ) EDS spectrum of point $1 ; d$ ) analysis of chemical composition (results of point analysis)
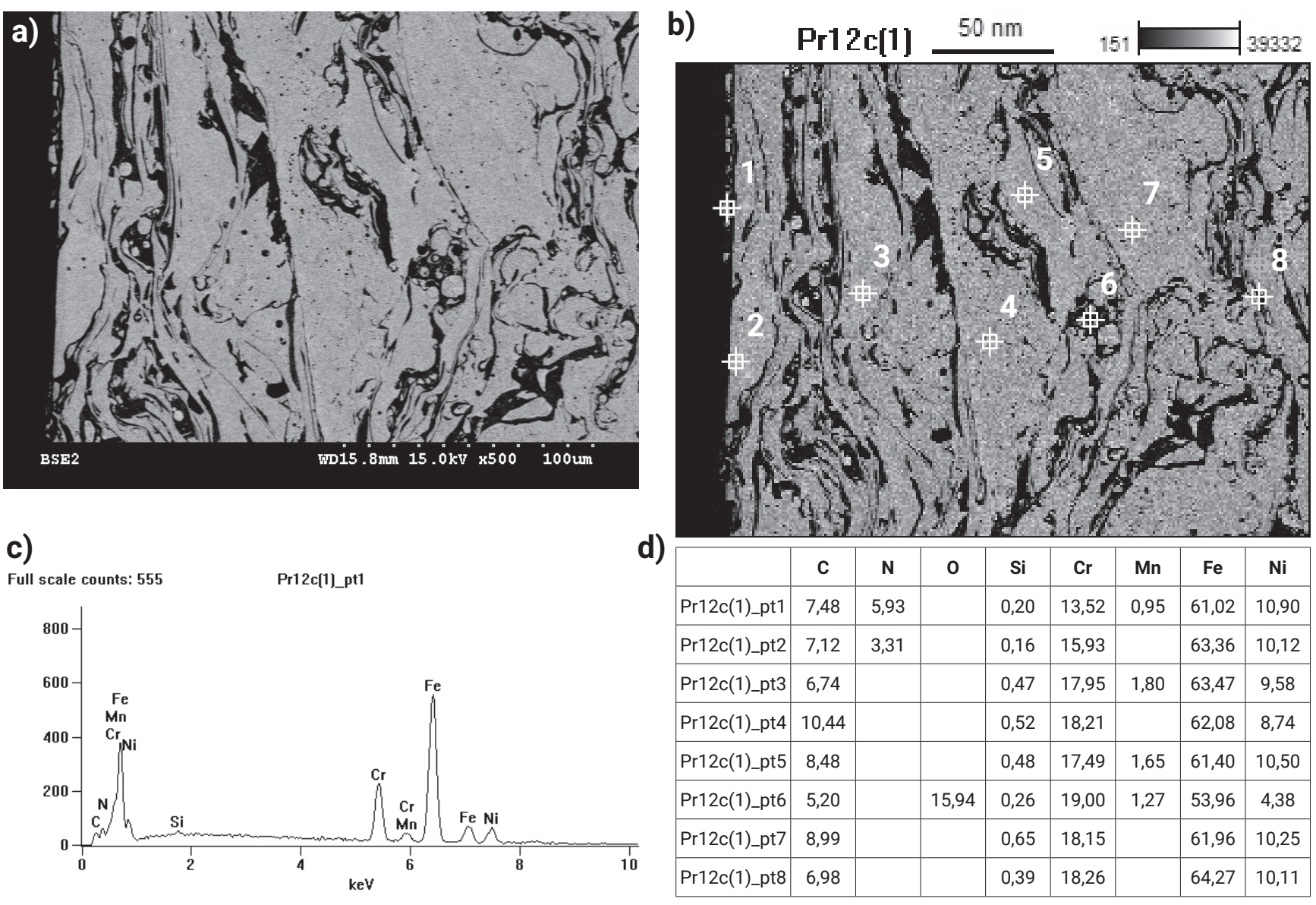

c)

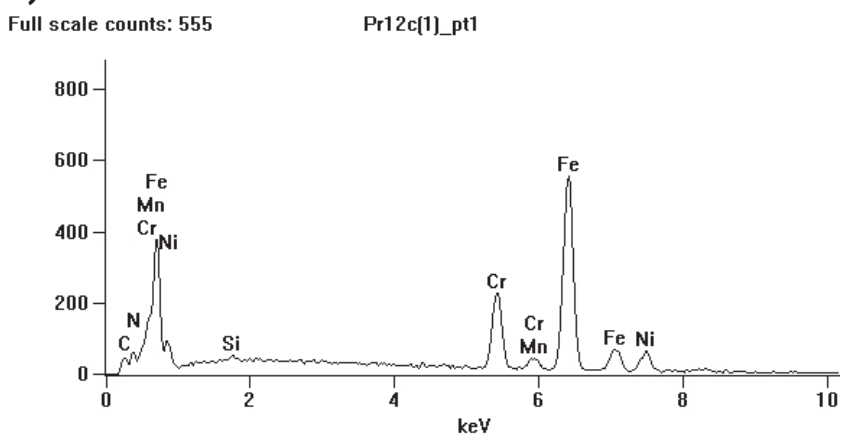

Fig. 3. Coating sprayed of $\mathrm{X} 2 \mathrm{CrNi} 18-9$ steel after nitriding at $450^{\circ} \mathrm{C}, 6 \mathrm{~h}$ : a) SEM images of the test sample; b) SEM images of the test sample with marking of the analyzed points; c) EDS spectrum of point 1; d) analysis of chemical composition (results of point analysis) 


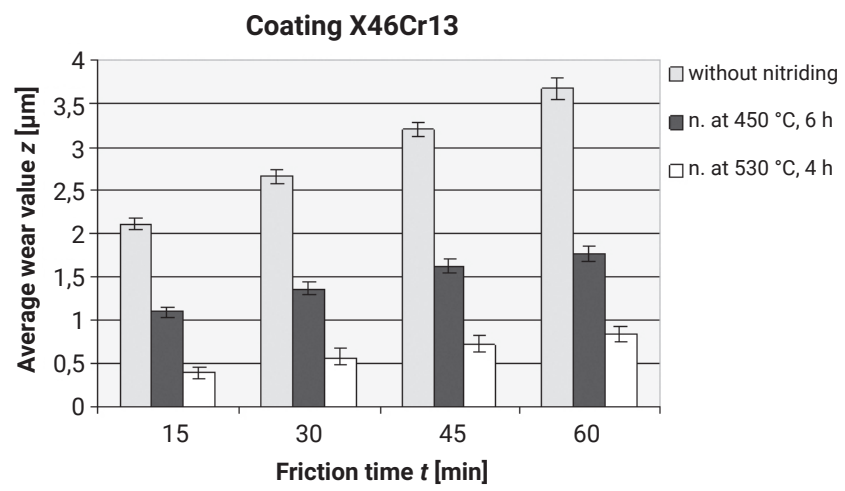

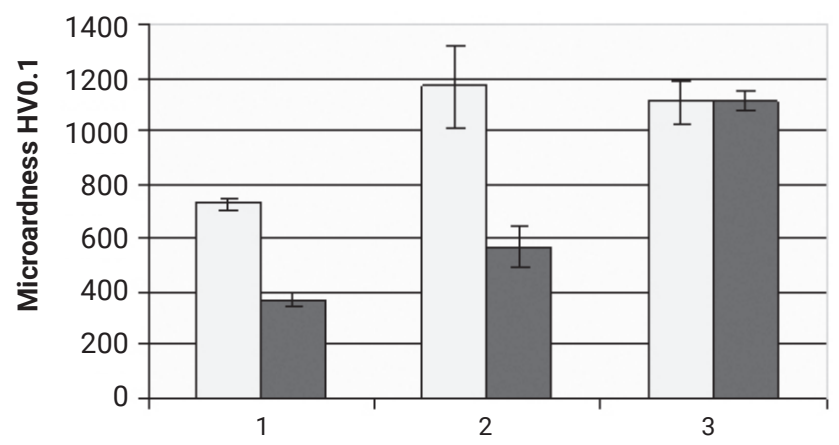

Fig. 4. Microhardness HV0.1 of coatings sprayed of $\mathrm{X} 46 \mathrm{Cr} 13$ and $\mathrm{X} 2 \mathrm{CrNi18-9:} 1$ - before nitriding; 2 - after nitriding at $450{ }^{\circ} \mathrm{C}, 6 \mathrm{~h} ; 3$ after nitriding at $530^{\circ} \mathrm{C}, 4 \mathrm{~h}$

24- $0,443 \mathrm{~mm}$

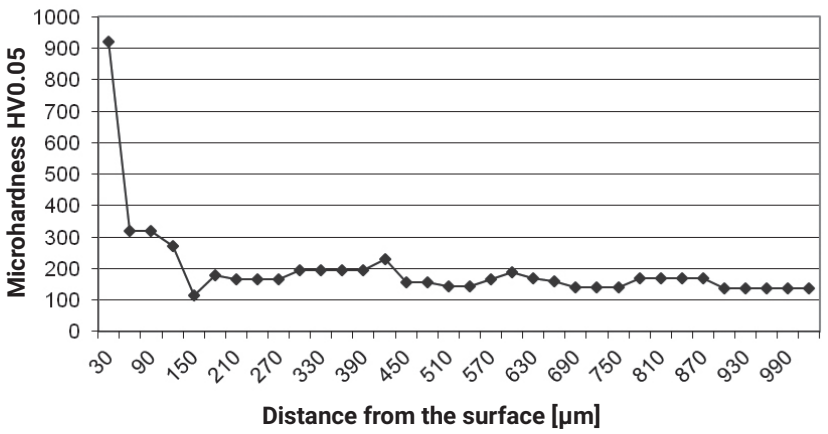

Fig. 5. Distribution of HV0.05 microhardness on a sample with thermally sprayed coating of $\mathrm{X} 46 \mathrm{Cr} 13$ nitrided at $530{ }^{\circ} \mathrm{C}, 4 \mathrm{~h}$
Fig. 6. Average wear value of thermally sprayed coatings made of $\mathrm{X} 46 \mathrm{Cr} 13$ steel without nitriding and nitrided at $450{ }^{\circ} \mathrm{C}, 6 \mathrm{~h}$ and at $530{ }^{\circ} \mathrm{C}, 4 \mathrm{~h}$ depending on the time of friction

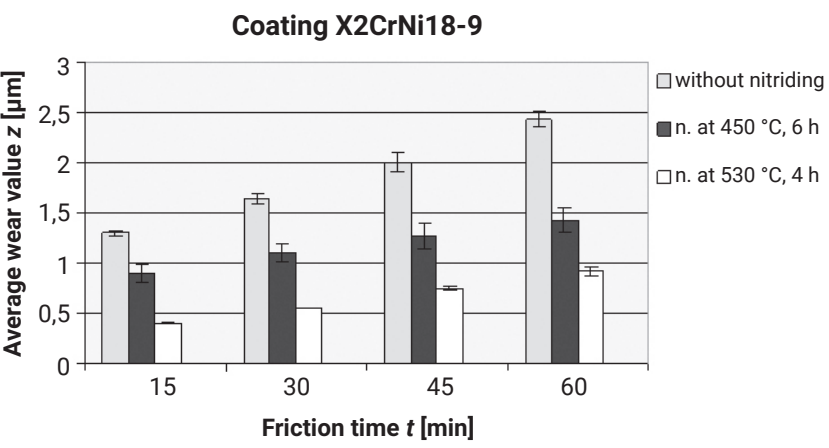

Fig. 7. Average wear value of thermally sprayed coatings made of $\mathrm{X} 2 \mathrm{CrNi} 18-9$ steel without nitriding and nitriding at $450{ }^{\circ} \mathrm{C}, 6 \mathrm{~h}$ and at $530{ }^{\circ} \mathrm{C}, 4 \mathrm{~h}$ depending on the time of friction

Table I. Roughness parameters of thermally sprayed coatings before and after glow-discharge nitriding

\begin{tabular}{|c|c|c|c|c|c|c|}
\hline \multirow{2}{*}{ Coating } & \multicolumn{2}{|c|}{ Before nitriding } & \multicolumn{2}{|c|}{ Nitriding at $450^{\circ} \mathrm{C}, 6 \mathrm{~h}$} & \multicolumn{2}{|c|}{ Nitriding at $530^{\circ} \mathrm{C}, 4 \mathrm{~h}$} \\
\hline & $\mathrm{Ra}[\mu \mathrm{m}]$ & $\mathrm{Rz}[\mu \mathrm{m}]$ & $\mathrm{Ra}[\mu \mathrm{m}]$ & $\mathrm{Rz}[\mu \mathrm{m}]$ & $\mathrm{Ra}[\mu \mathrm{m}]$ & $\mathrm{Rz}[\mu \mathrm{m}]$ \\
\hline $\mathrm{X} 46 \mathrm{Cr} 13$ & 0.38 & 2.97 & 0.41 & 3.9 & 0.51 & 4.00 \\
\hline X2CrNi18-9 & 0.43 & 2.83 & 0.47 & 3.80 & 0.46 & 3.46 \\
\hline
\end{tabular}

\section{Conclusions}

1. The glow-discharge nitriding increases the hardness and wear resistance due to the friction of the $\mathrm{X} 46 \mathrm{Cr} 13$ and $\mathrm{X} 2 \mathrm{CrNi} 18-9$ stainless steel thermally sprayed coatings.

2. Glow-discharge nitriding at $530^{\circ} \mathrm{C}$ for $4 \mathrm{~h}$ of thermally sprayed $\mathrm{X} 46 \mathrm{Cr} 13$ steel coatings creates a surface diffusion layer with a thickness of approx. $50 \mu \mathrm{m}$, characterized by high hardness (1108 HV0.1) and very good resistance to wear due to friction. Similar hardness and wear resistance were obtained for X2CrNi18-9 sprayed coatings after glow-discharge nitriding, but diffusion of nitrogen into the coating was uneven.

3. After low-temperature glow-discharge nitriding at $450{ }^{\circ} \mathrm{C}$ for 6 hours of thermally sprayed $\mathrm{X} 46 \mathrm{Cr} 13$ steel coatings, the surface hardness increases to $1165 \mathrm{HV} 0.1$. It also increases resistance to friction wear, but it is lower than after nitriding at $530^{\circ} \mathrm{C}$ for 4 hours. However, on the surface of the X2CrNi18-9 sprayed coating, a very thin, hard layer (1048 HV0.01) is created with a similar wear resistance as in the $\mathrm{X} 46 \mathrm{Cr} 13$ steel coating. 


\section{References}

[1] W. Milewski, Nowoczesne kierunki rozwoju technologii natryskiwania cieplnego, 44. Naukowo-Techniczna Konferencja Spawalnicza „Postęp i innowacje w spawalnictwie" WROCŁAW 2002.

[2] W. Żórawski, Nowe kierunki rozwoju natryskiwania cieplnego w produkcji części maszyn, Inżynieria Powierzchni (2011), nr 3, 10-17.

[3] T. Hejwowski, Nowoczesne powłoki nakładane cieplnie odporne na zużycie ścierne i erozyjne. Monografia, Politechnika Lubelska, Lublin 2013.

[4] W. Milewski, A. Nakonieczny, A. Olbrycht, Dotychczasowe doświadczenia z przemysłowego zastosowania w Polsce powłok ochronnych natryskiwanych cieplnie, Ochrona przed Korozją (2011), nr 7, 435-437.

[5] T. Babul, Możliwości natryskiwania UDDP+Ni na stal 17CrNiMo6, Przegląd Spawalnictwa (2009), vol. 81(9), 86-89.

[6] T. Babul, Podstawy procesu natryskiwania detonacyjnego powłok NiCrBSi i WC/Co. Monografia, Instytut Mechaniki Precyzyjnej, Warszawa, 2011.

[7] A. Olbrycht, Powłoki metalowe jako zabezpieczenie antykorozyjne konstrukcji stalowych, Przegląd Spawalnictwa (2014), vol. 86(2), 2-6.

[8] W. Milewski, A. Olbrycht, S. Pawlik: Wpływ rodzaju układu rozpylającego i sposobu natryskiwania na koszty wykonania powłok natryskanych łukowo, Przegląd Spawalnictwa (2012), vol. 84(9), 14-19.

[9] J. Wojdak, P. Sędłak, P. Wanke, T. Stawicki, Analiza rozwoju metod regeneracji części maszyn w aspekcie przemian gospodarczych, Inżynieria Rolnicza (2009), 1(110), 347-352.
[10] T. Borowski, J. Kamiński, J. Trojanowski, T. Wierzchoń, Analiza struktury i właściwości warstw azotowanych wytworzonych na stali $316 \mathrm{~L}$ w różnych obszarach wyładowania jarzeniowego, Archiwum Technologii Maszyn i Automatyzacji (2010), vol. 30(3), 69-77.

[11] P. Wach, A. Ciski, J. Tacikowski, T. Babul, S. Tirak, P. Šuchmann, Możliwości obróbki cieplnej warstw azotowanych wytworzonych na stalach, Inżynieria Powierzchni (2017), nr 1, 48-54.

[12] J. Flis, Azotowanie plazmowe i jego wpływ na odporność korozyjną stali nierdzewnych, Ochrona przed korozją (2005), nr 4, 86-89.

[13] L. Berkowski, Właściwości azotowanych powłok regeneracyjnych, Obróbka Plastyczna Metali (2011), t. XXII nr 1, 15-29.

[14] A. Byeli V., M.A. Belotserkovskii, V.A. Kukareko, Microstructure and wear resistance of thermal sprayed steel coatings ion beam implanted with nitrogen, Wear (2009), 267, 1757-1761.

[15] S. Adach, N. Ueda, Formation of S-phase layer on plasma sprayed AISI $316 \mathrm{~L}$ stainless steel coating by plasma nitriding at low temperature, Thin Solid Films (2012), 523, 11-14

[16] PN-82/H-04332 Badania wytrzymałościowe metali - Badanie zużycia metali lub ich warstw dyfuzyjnych w procesie tarcia ślizgowego przy stałym nacisku na maszynie Amslera. 